\title{
Valor cultural de especies arbóreas en sistemas agroforestales de la Sierra de Huautla, Morelos*
}

\author{
Cultural value of tree species in agroforestry systems in \\ the mountain range of Huautla, Morelos
}

\author{
Bogard Burgos Herrera ${ }^{1}$, Artemio Cruz León ${ }^{2 \S}$, Miguel Uribe Gómez ${ }^{2}$, Alejandro Lara Bueno ${ }^{2}$ y Ranferi Maldonado Torres ${ }^{2}$ \\ ${ }^{1}$ Posgrado en Ciencias Agroforestería para el Desarrollo Sostenible-Universidad Autónoma Chapingo. Carretera. México-Texcoco km 38.5, Chapingo, Texcoco. C. P. \\ 56230, Estado de México. Tel: 595952 540. (camilo303@hotmail.com). ${ }^{2}$ Universidad Autónoma Chapingo. Carretera. México-Texcoco, km 38.5, Chapingo, Texcoco. \\ C.P.56230,Estado de México.Tel: 595952 1540.(alarab_11@hotmail.com; migueluribe123@gmail.com). ${ }^{\S}$ Autor para correspondencia: etnoagronomia1@gmail.com.
}

\section{Resumen}

La Sierra de Huautla se ubica al sur del estado de Morelos. En 1999 fue decretada como Reserva de la Biósfera Sierra de Huautla (Rebiosh), por la presencia de la selva baja caducifolia (SBC). Dentro de la reserva se encuentran comunidades rurales cuya dotación ejidal fue afectada por el decreto de La Rebiosh. Los habitantes han utilizado los recursos vegetales de SBC, que se refleja en el conocimiento de este tipo de vegetación, aprovechamiento y manejo de la mayoría de especies vegetales y animales. El objetivo de esta investigación fue identificar especies arbóreas de uso múltiple para conocer aquellas con alto valor de uso, e identificar el conocimiento tradicional en el manejo consciente de los recursos florísticos de la Rebiosh. Se realizaron entrevistas semiestructuradas para conocer el uso de las especies y poder calcular el índice de valor cultural (IC) de las especies arbóreas, también se realizaron muestreos en los sistemas de manejo con tecnologías agroforestales para calcular el índice de valor de importancia (VI) y determinar la selección de especies aprovechadas. Se encontró el IC con mayores valores para: Eysenhardtia polystachia con 90\%, Mimosa benthamii con $82 \%$, Haematoxilum brasiletto con $68 \%$ y Crescentia alata con 57\%. Para VI resaltaron: Mimosa benthamii con $114 \%$ y Crescentia alata con 50\%, entre otras. Concluimos

\section{Abstract}

The mountain range of Huautla is located south of the state of Morelos. In 1999 it was declared as Biosphere Reserve mountain range of Huautla (Rebiosh), by the presence of the tropical dry forest (SBC). Within the reserve are rural communities whose common endowment was affected by the decree of the Rebiosh. The people have used SBC plant resources, reflected in knowledge of this type of vegetation, use and management of most plant and animal species. The objective of this research was to identify tree species purpose to meet those high use value, and identify traditional knowledge in the conscious management of resources floristic Rebiosh. The semi-structured to meet the use of species and to calculate the index of cultural value (IC) of tree species interviews were conducted, samples were also made in the management systems with agroforestry technologies to calculate the index of importance value (VI) and determine the selection of exploited species. IC found higher values for: Eysenhardtia polystachia with $90 \%, 82 \%$ Mimosa benthamii, Haematoxilum brasiletto with 68\% and 57\% Crescentia alata. To VI they highlighted: Mimosa benthamii with $114 \%$ and $50 \%$ Crescentia alata, among others. We conclude that the people of Ajuchitlan been selected tree species for their use, creating agroforestry as a sustainable strategy.

\footnotetext{
* Recibido: marzo de 2016 
que los pobladores de Ajuchitlán han seleccionado especies forestales para su aprovechamiento, creando sistemas agroforestales como estrategia sostenible.

Palabras clave: agroforestería, Sierra de Huautla, valor cultural, valor de importancia.

\section{Introducción}

La Sierra de Huautla se ubica al surdel estado de Morelos, limita con los estados de Pueblay Guerrero. Dada la importancia de la Selva baja daducifolia (SBC)(Miranda y Hernández, 1963), o bosque tropical caducifolio, Rezendowski,(2006), que en ella se encuentra y como resultado de los trabajos de investigación realizados por personal de la Universidad Autónoma de Morelos, en 1999 fue decretada como Reserva de la Biosfera Sierra de Huautla (REBIOSCH), (Dorado et al., 1995). Dentro de la reserva se encuentran comunidades rurales cuya dotación ejidal fue afectada por el decreto de La REBIOSCH. Los habitantes han utilizado los recursos vegetales de SBC, que se refleja en el conocimiento de este tipo de vegetación, aprovechamiento y manejo de la mayoría de especies vegetales y animalesMéxico es consideradouno de los países con mayor diversidad tanto biológica y cultural en el mundo.

(Toledo, 2012), cuenta con 30 grupos de vegetación(Miranda y Hernández, 1963) y representa la segunda gran riqueza biocultural del mundo con 68 agrupaciones lingüísticas y 364 variantes de lenguas indígenas. Gracias a esto se construyóuno de los universos civilizatorios más importantes del mundo, se crearon y modelaron nuevos paisajes y se permitió el surgimiento de modelos productivos utilizando los recursos naturales, lo que dio como resultado más de cien especies domesticadas y una herbolaria compuesta por más de 4 mil especies, generando una memoria cultural a lo largo de casi 9 mil años, lo que representa la parte medular del patrimonio biocultural de México (Toledo, 2012).

La SBC está considerada como una gran reserva de recursos genéticos por su alto grado de especies nativas que presentan múltiplesutilidades para el hombre (Dirzo, 1996). Un estudio realizado por Argueta (1994) evidencia que es en este tipo de vegetación donde los pobladores utilizan alrededor de $55 \%$ de las especies vegetales presentes, siendo las medicinales las de mayor número. Los recursos florísticos de la SBC han
Keywords: agroforestry, cultural value, importance value, Sierra of Huautla.

\section{Introduction}

The mountain range of Huautla is located south of the state of Morelos, bordering the states of Puebla and Guerrero. Given the importance of the low tropical dry forest (SBC) (Miranda and Hernández, 1963), or tropical deciduous forest, Rezendowski, (2006), it is as a result of the research work carried out by staff of the University Autonomous of Morelos in 1999 was declared as Biosphere Reserve mountain range of Huautla (REBIOSCH), (Dorado et al., 1995). Within the reserve are rural communities whose common endowment was affected by the decree of the REBIOSCH. The people have used plant resources of SBC, reflected in knowledge of this type of vegetation, use and management of most plant species and animals in México is considered one of the countries with the highest both biological and cultural diversity in the world.

Toledo (2012), has 30 groups of vegetation (Miranda and Hernández, 1963) and represents the second great biocultural wealth of the world with 68 groups and 364 linguistic variants indigenous languages. Thanks to this built one of the most important civilizational universes of the world, were created and modeled new landscapes and the emergence of production models allowed using natural resources, which resulted in over a hundred domesticated species, and a herbalist comprising more 4 thousand species, creating a cultural memory along almost 9000 years, which represents the core of the biocultural heritage of Mexico (Toledo, 2012).

The SBC is considered a large reservoir of genetic resources for their high degree of native species with multiple uses for man (Dirzo, 1996). A study by Argueta (1994) evidence is in this type of vegetation where residents use about $55 \%$ of plant species, medicinal being the largest number. The floristic resources of the SBC have been part of the culture of the communities living in the area of distribution of this type of vegetation; this use has generated knowledge associated with the use of vegetation as medicine, food, construction and hedgerows, among others (Monroy and Ayala, 2003). 
formado parte de la cultura de las comunidades que habitan en el área de distribución de este tipo de vegetación; este aprovechamiento ha generado conocimientos asociado al uso de la vegetación como medicina, alimento, construcción y cercas vivas, entre otros (Monroy y Ayala, 2003).

Este tipo de conocimiento es denominado como conocimiento campesino o saberes agrícolas locales (Díaz et al., 2004). Existe la idea de que se trata solamente de la supervivencia de prácticas antiguas yes descalificado por el conocimiento científico occidental porestar ligado a prácticas religiosas; los cambios sociales actuales han propiciado la desintegración y degradación de los sistemas de saberes locales, incrementando el riego de pérdida por la ausencia de registros de este tipo de conocimient (Pérez y Argueta, 2011).

Es por ello imprescindible resaltar la importancia que tiene el conocimiento campesino, ya que éste domina su medio y distingue aquellos recursos que poseen características deseables y aportan beneficios (Altieri, 1993). Levi-Strauss, citado por Pérez y Argueta (2011), expuso primeramente la necesidad de legitimar, sistematizar, escribir, formalizar o convalidar los saberes tradicionales, asumiendo que se requieren para ello instrumentos de la ciencia occidental, para pasar de un saber difuso hacia un conocimiento objetivo; es decir, pasar de la validez local a la validez universal.

Con base en lo anterior, el presente estudio tiene como objetivo identificar y calcular la importancia de las especies vegetales útiles en las diferentes tecnologías agroforestales, para incorporar el conocimiento tradicional a los procesos de investigación y al desarrollo de nuevas tecnologías, así contribuir a generar y establecer bases para el diseño de nuevas propuestas agroforestales en el aprovechamiento y conservación de los recursos de la SBC.

\section{Materiales y métodos}

\section{Revisión bibliográfica}

Se revisaron los estudios más recientes realizados sobre el área de estudio y la temática, en particular de los sistemas agroforestales así como de la importancia cultural y ecológica de las especies presentes en la SBC en el estado de Morelos, tomando como referencia los estudios etnobotánicos y aquellos que incluyeran el conocimiento tradicional de especies arbóreas en la Sierra de Huautla Morelos.
This type of knowledge is known as farmers' knowledge or local agricultural knowledge (Díaz et al., 2004). There is the idea that it is only the survival of ancient practices and is disqualified by the western scientific knowledge to be linked to religious practices; current social changes have led to the disintegration and degradation of local knowledge systems, increasing the risk of loss due to the absence of records of such knowledge (Pérez and Argueta, 2011).

It is therefore essential to highlight the importance of farmers' knowledge, since it dominates its environment and distinguishes those resources that they possess desirable characteristics and provide benefits (Altieri, 1993). LeviStrauss, cited by Pérez and Argueta (2011), first exposed the need to legitimize, systematizing, writing, formalize and validate traditional knowledge, assuming that it instruments of Western science required to move from a fuzzy knowing objective knowledge; i.e. move from the local validity to the universal validity.

Based on the above, this study aims to identify and calculate the importance of plant species useful in different agroforestry technologies to incorporate traditional knowledge to the processes of research and development of new technologies and help to generate and establish bases for the design of new agroforestry proposals in the use and conservation of the resources of the SBC.

\section{Materials and methods}

\section{Literature review}

The most recent studies on the study area and the subject, particularly agroforestry systems as well as cultural and ecological importance of the species in the SBC in the state of Morelos were reviewed, with reference to the ethnobotanical studies and those include traditional knowledge of tree species in the mountain range of Huautla, Morelos.

\section{Interviews}

In order to obtain information from forest management in various systems, semi-structured interviews were applied to people engaged in agriculture, livestock and forestry, on the age range of 20 producers to 60 years; thus, $80 \%$ 


\section{Entrevistas}

Con el fin de obtener información del manejo forestal en los diferentes sistemas, se aplicaron entrevistas semiestructuradas a personas dedicadas a las actividades agrícolas, ganaderas y forestales, tomando como rango de edades a productores de 20 a 60 años; de este modo, $80 \%$ de los entrevistados sobrepasaron los 50 años de edad. En la entrevista se tomaron datos generales tales como: nombre del productor, edad, superficie agrícola y forestal aprovechada que a lo largo del año es necesaria y permite obtener ingresos económicos. De la misma forma la entrevista incluyó un apartado específico del manejo forestal y su aprovechamiento a lo largo del año, y del conocimiento de las diferentes especies arbóreas, basado en la utilidad que tienen a estas especies forestales a través del tiempo, esto con el fin de obtener el índice de valor cultural de las especies arbóreas.

\section{Î́ndice de importancia cultural de las especies arbóreas}

El valor cultural de las especies arbóreas se determinó mediante el índice de importancia cultural propuesto por Figueroa (2000) y utilizado por Otero (2005). Para ello fue necesaria la construcción de una matriz de doble entrada, la cual permitió cuantificar los valores: intensidad de uso, frecuencia de mención y valor de uso, necesarios para la obtención del índice de importancia cultural.

El índice de importancia cultural utilizado tiene la siguiente expresión matemática:

$\mathrm{IIC}=\Sigma\left(\mathrm{Iuz}_{\mathrm{Z}}+\mathrm{Fm} \mathrm{Z}+\mathrm{Vutz}\right)$

Donde: $\mathrm{IIC}=$ índice de importancia cultural, comola sumatoria de la intensidad de uso, frecuencia de mención y valor de uso; Iuz = intensidad de uso, considerada como el porcentaje de uso para una especie vegetal $z ; F m z=$ frecuencia de mención, considerada como el porcentaje de menciones para la especie vegetal $z$ del total para todos los usos entre todos los informantes; Vutz= el valor de uso total para la especie vegetal $z$, como la sumatoria de todos los valores de uso de la especie $z$ en la categoría de uso x de (Vux) a (vun).

\section{Valor de importancia e índices ecológicos de diversidad florística}

Para obtener el valor de importancia de las especies arbóreas y arbustivas de los sistemas agroforestales de la Sierra de Huautla, se seleccionaron sistemas representativos con manejo of respondents exceeded 50 years of age. In the interview general data such as were taken: producer's name, age, agricultural land and forestry exploited that throughout the year is necessary and allows income. In the same way the interview included a specific section of forest management and utilization throughout the year, and knowledge of the different tree species, based on the utility of these forest species over time, this in order to get the index of cultural value tree species.

\section{Index cultural importance of tree species}

The cultural value of tree species was determined by the rate of cultural importance proposed by Figueroa (2000) and used by Otero (2005). This required the construction of a double entry matrix, which allowed quantify the values: intensity of use, frequency of mention and use value, necessary for obtaining the index of cultural significance.

The cultural significance index used has the following mathematical expression:

$\mathrm{IIC}=\Sigma\left(\mathrm{Iu}_{\mathrm{Z}}+\mathrm{Fm} \mathrm{Z}+\mathrm{Vutz}\right)$

Where: IIC = index of cultural significance, as the sum of the intensity of use, frequency of mention and use value; Iuz= intensity of use, considered as the percentage of use for a plant species z; Fmz= frequency of mention, considered the percentage of mentions for $\mathrm{z}$ plant species of the total for all uses among all informants; Vutz= the value of total usage for the plant species $\mathrm{z}$, as the sum of all values of $z$ use of the species in the category of use $x$ (Vux) to (vun).

\section{Ecological importance and value of floristic diversity indices}

For the importance value of tree and shrub species of agroforestry systems in the mountain range of Huautla, representative systems with agroforestry and silvopastoral management were selected, for which they were drawn at random transects, based sampling unit an area of $100 \mathrm{~m}^{2}$, forming a rectangle with lines 5 meters wide by 16 meters long, which was divided into 4 intervals measuring $20 \mathrm{~m}^{2}$ each $(5 \times 4)$ (Figure 1).

In the four measurement intervals tree and shrub species present were recorded: common name, frequency and dominance in each interval of appearance. 
agrosilvopastoril y silvopastoril, para lo cual se trazaron de forma aleatoria transectos, tomando como unidad de muestreo un área de $100 \mathrm{~m}^{2}$, formando un rectángulo con líneas de 5 metros de ancho por $16 \mathrm{~m}$ de largo, el cual se subdividió en 4 intervalos de medición de $20 \mathrm{~m}^{2}$ cada uno (5 x 4) (Figura 1).

En los cuatro intervalos de medición se registraron las especies arbóreas y arbustivas presentes: nombre común, frecuencia y dominancia en cada intervalo de aparición.

En cada sistema de muestreo se realizaron dos transectos para el registro de las especies vegetales, obteniendo 10 líneas en total, con 20 m de separación entre líneas.

La captura, sistematización y análisis de la información obtenida se realizó en hojas de cálculo Excel 2010.

\section{Recolección de material botánico}

Se realizaron colectas de material botánico durante los transectos, siguiendo la metodología de Loty Chiang(1986), para la posterior identificación de las especies vegetales presentes, con ayuda de una prensa botánica de madera con medida estándar de $30 \times 42 \mathrm{~cm}$; se colectaron tres o cuatro ejemplares de cada especie vegetal; además, se sustentó la colecta con material fotográfico, como ayuda para la identificación de las especies colectadas, registrándose nombre común, intervalo de aparición en la línea de transecto y fecha de colecta, coincidiendo con el material fotográfico.

\section{Resultados}

\section{Aprovechamiento forestal en el ejido de Ajuchitlán}

El aprovechamiento forestal es un proceso de transformación de bienes naturales en bienes de consumo familiar. La zona agrícola se maneja con tecnologías agroforestales como medio de reproducción de especies forestales para el aprovechamiento maderable, medicinal, alimenticio, forrajero, ceremonial, ornamental, etcétera, como es el caso del tecolhuixtle (Mimosa bentamhii), que provee de postes de excelente calidad para la reparación de cercos y corrales de manejo; el cuachalalate (Amphipterygium adstringens), árborea de gran importancia cultural y alto valor medicinal en todo el territorio de la Sierra de

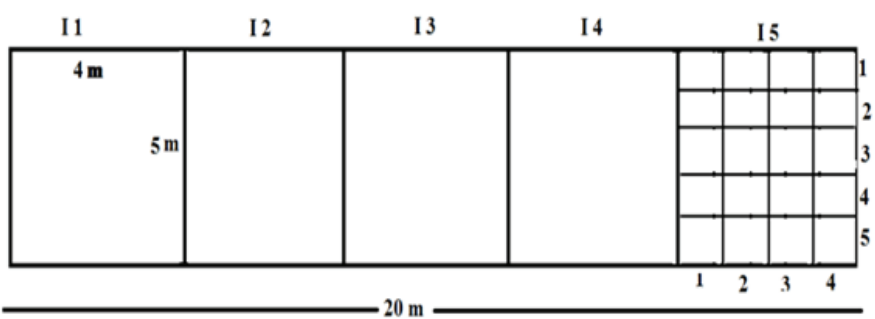

Figura 1. Área de muestreo y sus divisiones para árboles y arbustos.

Figure 1. Sampling area and its divisions for trees and shrubs.

In each two transects sampling system for the registration of plant species they were carried out, obtaining 10 lines in total, with $20 \mathrm{~m}$ line spacing.

Capture, systematize and analyze the information obtained was done in sheet calculation Excel 2010.

\section{Collection of botanical material}

collections of botanical material were made during the transects, following the methodology of Lot and Chiang (1986), for later identification of plant species present, using a wooden press botanical standard measure of $30 \times 42 \mathrm{~cm}$; three or four copies of each plant species were collected; in addition, the collection was based photographic material as an aid to identifying the species collected, registering common name, appearance interval line transect and date of collection, coinciding with the photographic material.

\section{Results}

\section{Forestry in the common of Ajuchitlán}

The forestry is a process of transforming natural resources into goods for household consumption. The agricultural area is managed with agroforestry technologies as a means of reproduction of forest species for timber, medicinal, food, forage, ceremonial, ornamental use, etc., as in the case of tecolhuixtle (Mimosa bentamhii), which provides poles of excellent quality for repairing fences and corrals management; the cuachalalate (Amphipterygium adstringens), tree of great cultural importance and high medicinal value throughout the territory of the mountain 
Huautla; palo Brasil (Heamatoxylum brassileto), especie de usos múltiples que se usa como leña y posee propiedades medicinales; palo dulce (Einserhactia polystachia), especie medicinal y durabilidad como postes de cercos; cuatecomate (Crescentia alata), especie con valor medicinal y comercial, ya que algunas personas de la comunidad recolectan su fruto para la venta en el exterior. Dentro del sistema agrosilvopastoril se encuentran las siguientes especies útiles (Cuadro 1). range of Huautla; brazilwood(Heamatoxylum brassileto), multipurpose species used as firewood and has medicinal properties; licorice (Einserhactia polystachia), medicinal species and durability as fence posts; Cuatecomate (Crescentia alata), a species with medicinal and commercial value, as some people in the community gather fruit for sale abroad. The agrosilvopastoral are within the system the following useful species (Table 1).

Cuadro 1. Especies arbóreas y su aprovechamiento en los sistemas agroforestales del ejido de Ajuchitlán, Sierra de Huautla, Morelos.

Table 1. Tree species and their use in agroforestry systems common Ajuchitlán, mountain range of Huautla, Morelos.

\begin{tabular}{lll}
\hline Nombre común & Nombre científico & Aprovechamiento \\
\hline Copal & Bursera bipinnata & Resinas \\
Cuachalalate & Amphipterygium adstringens & Medicinal \\
Cuatecomate & Crescentia alata & Medicinal, forraje, leña, postes, frutos, \\
Cubata & Acacia cochliacantha & leña \\
Grangel & Randia echinocarpa & Leña, forraje \\
Cuahulote & Guazuma ulmifolia & Medicinal \\
Mata rata & Gliricidia sepium & Forraje, leña \\
& & Forraje, leña, cercos vivos \\
Palo Brasil & Haematxylum brasiletto & \\
Querengue & Vitex pyramidata & Medicinal, forraje, leña \\
Quiebracho & Lonchocarpus rugosus & Leña, postes \\
Tecolhuixtle & Mimosa benthamii & Postes, leña \\
Tepehuaje & Lysiloma acapulcense & Postes, leña, forraje \\
\hline
\end{tabular}

Al igual que la producción agrícola, las actividades forestales están íntimamente ligadas a las ganaderas, principal fuente de ingresoseconómicos; sin embrago, el conocimiento dela región para la integración de los recursos disponibles de la SBC ha permitidoa los productores desarrollar sistemas sustentables en elaprovechamiento de los recursosnaturales para lasubsistencia y reproducción de las unidades de producción familiar.

\section{Valor cultural de las especies arbóreas en los sistemas agroforestales en el ejido de Ajuchitlán}

Se obtuvo el índice de valor cultural de las especies arbóreas presentes en la SBC con base en el uso que les dan los habitantes de Ajuchitlán (Cuadro 2).
As agricultural production, forestry activities are closely linked to livestock, the main source of income; no clutch, knowledge of the region to integrate resources available SBC has enabled producers develop sustainable systems in the use of natural resources for subsistence and reproduction of family production units.

\section{Cultural value of tree species in agroforestry systems in the common of Ajuchitlán}

The cultural value index was obtained of tree species present in the SBC based on the use that give them the inhabitants of Ajuchitlán (Table 2). 
Cuadro 2. Índice de valor cultural estimado para las especies arbóreas por su importancia para los habitantes de Ajuchitlán. Table 2. Estimated cultural value index for tree species due to its importance for the habitants of Ajuchitlán.

\begin{tabular}{|c|c|c|c|c|c|}
\hline $\begin{array}{l}\text { Nombre } \\
\text { común }\end{array}$ & Nombre científico & $\begin{array}{l}\text { Valor de uso } \\
\text { total por especie } \\
\text { (Vutz) }\end{array}$ & $\begin{array}{l}\text { Frecuencia de } \\
\text { mención } \\
(\text { Fmz })\end{array}$ & $\begin{array}{l}\text { Intensidad } \\
\text { de usos } \\
\text { (Iuz) }\end{array}$ & $\begin{array}{c}\text { Índice de } \\
\text { valor cultural } \\
\Sigma(\text { Iuz+Fmz+Vutz })\end{array}$ \\
\hline Pochote & Ceiba aesculifolia & 6 & 2.59 & 12.98 & 21.58 \\
\hline Querengue & Vitex pyramidata & 2 & 0.86 & 4.32 & 7.19 \\
\hline Paraca & Senna skinneri & 5 & 2.16 & 10.82 & 17.98 \\
\hline Palo mulato & Bursera simaruba & 3 & 1.29 & 6.49 & 10.79 \\
\hline Guayacan & Miroxylom & 10 & 4.32 & 21.64 & 35.97 \\
\hline Amarillo & Balsamum & & & & \\
\hline Mata piojo & Hippocratea acapulcensis & 3 & 1.29 & 6.49 & 10.79 \\
\hline Copal chino & Bursera bipinnata & 4 & 1.73 & 8.65 & 14.38 \\
\hline Chupandilla & Cyrtocarpa procera & 1 & 0.43 & 2.16 & 3.59 \\
\hline Cuahulote & Guazuma ulmifolia & 6 & 2.59 & 12.98 & 21.58 \\
\hline Mezquite & Prosopis laevigata & 3 & 1.29 & 6.49 & 10.79 \\
\hline Amate & Ficus spp. & 4 & 1.73 & 8.65 & 14.38 \\
\hline Guachocote & Malpighia mexicana & 4 & 1.73 & 8.65 & 14.38 \\
\hline Carpinceran & Dalbergia congestiflora & 3 & 1.29 & 6.49 & 10.79 \\
\hline Guayaba & Psidium guajava & 4 & 1.73 & 8.65 & 14.38 \\
\hline Encino & Quercus castanea & 2 & 0.86 & 4.32 & 7.19 \\
\hline Tecolhuixtle & Mimosa benthamii & 23 & 9.95 & 49.78 & 82.74 \\
\hline Palo dulce & Eysenhardtia polystachia & 26 & 11.25 & 56.27 & 93.53 \\
\hline Palo brasil & $\begin{array}{c}\text { Haematoxylum } \\
\text { Brasiletto }\end{array}$ & 19 & 8.22 & 41.12 & 68.35 \\
\hline Teclatía & & 4 & 1.73 & 8.65 & 14.38 \\
\hline Mata rata & Gliricidia sepium & 6 & 2.59 & 12.98 & 21.58 \\
\hline Cuachalalate & Amphipterygium adstringens & 14 & 6.06 & 30.3 & 50.36 \\
\hline Cuatecomate & Crescentia alata & 16 & 6.92 & 34.63 & 57.55 \\
\hline Bonete & Jacaratia mexicana & 4 & 1.73 & 8.65 & 14.38 \\
\hline Guamuchil & Pithecellobium dulce & 2 & 0.86 & 4.32 & 7.19 \\
\hline Ayoyote & Thevetia thevetioides & 3 & 1.29 & 6.49 & 10.79 \\
\hline Quina & Chinchona spp. & 1 & 0.43 & 2.16 & 3.59 \\
\hline Granjel & Randia echinocarpa & 1 & 0.43 & 2.16 & 3.59 \\
\hline Cazahuate & Ipomea arborescens & 2 & 0.86 & 4.32 & 7.19 \\
\hline Cuajiote & Bursera fagaraoides & 1 & 0.43 & 2.16 & 3.59 \\
\hline Ciruelo & Spondia purpurea & 11 & 4.76 & 23.8 & 39.57 \\
\hline Linaloe & Bursera aloexylon & 1 & 0.43 & 2.16 & 3.59 \\
\hline Tepemezquite & Lysiloma divaricata & 11 & 4.76 & 23.8 & 39.57 \\
\hline Pegahueso & Euphorbia fulva & 1 & 0.43 & 2.16 & 3.59 \\
\hline Palo de oro & Lonchocarpus caudatus & 1 & 0.43 & 2.16 & 3.59 \\
\hline Panicua & Cochlospermumvitifolium & 6 & 2.59 & 12.98 & 21.58 \\
\hline Zopilote & Swietenia humilis & 2 & 0.86 & 4.32 & 7.19 \\
\hline Cubata & Acacia cochliacanta & 12 & 5.19 & 25.97 & 43.16 \\
\hline Tzompacle & Erythrina americana & 4 & 1.73 & 8.65 & 14.38 \\
\hline
\end{tabular}


En el Cuadro 2 se ubican las especies que presentan un mayor índice cultural, esto nos refiere la importancia de aprovechamiento de esas especies dentro de la cultura propia de la comunidad; de esta forma tenemos a la especie Eysenhardtia polystachia (palo dulce) con el mayor índice cultural calculado, esta especie presenta más de un uso y el más importante de ellos es su aprovechamiento como postes, altamente apreciada por su durabilidad en cercos; los ejidatarios hablan de postes de esta especie que han alcanzado 70 años de duración, por ello su alto aprecio. Además es medicinal, maderable y combustible. Le sigue en importancia Mimosa benthamii (tecolhuixtle), la cual es aprovechada para la obtención de postes de alta calidad y duración en los cercos; domina el paisaje ganadero en el sistema agrosilvopastoril, por su capacidad de rebrote es favorecida para su crecimiento dentro del sistema.

\section{Valor de importancia de las especies arbóreas en el sistema agrosilvopastoril}

El aprovechamiento dado a las diferentes especies implica un cambio selectivo en el patrón de crecimiento de éstas, esta influencia determinada por el hombre es el factor principal que modifica los ecosistemas naturales en sistemas de aprovechamiento en muchas ocasiones sustentables. En el siguiente cuadro podemos notar el valor de importancia de las especies encontradas en el sistema agrosilvopastoril, donde la especie con mayor importancia para este sistema es el tecolhuixtle (mimosa benthamii) con $114 \%$, esto claramente demuestra la presión selectiva de los habitantes de Ajuchitlán hacia esta especia dadas sus características de aprovechamiento, de la misma forma podemos notar que el cuatecomate (Crescentia alata) presenta $50 \%$ de importancia dentro del sistema respecto al resto de las otras especies, también posee características deseables que permiten su permanencia dentro del sistema (Cuadro 3 ).

Las especies que se encuentran dentro de este sistema presentanmás de unuso, hay medicinalescomoelcuatecomata (Crescentia alata), cuachalalate (Amphipterygium adstringens), granjel (Randia echinocarpa) y palo Brasil (Haematxylum brasiletto), también sobresalen las de uso combustible como la cubata (Acacia cochliacantha), quiebracho (Lonchocarpus rugosus), palo Brasil (Haematxylum brasiletto), y las de valor forrajero como la guazima(Guazuma ulmifolia), mata rata(Gliricidia sepium) y la cubata (Acaciacochliacantha).
The Table 2 shows the species with greater cultural index is located, this tells us the importance of use of such species within the culture of the community; thus we have the kind Eysenhardtia polystachia (licorice) with the largest cultural index calculated, this species has more than one use and the most important is its use as poles, highly prized for its durability fences; peasant posts talk about this species who have reached 70 years of duration, so their high appreciation. It is also medicinal, timber and fuel. Next in importance Mimosa benthamii (tecolhuixtle), which is then used to obtain high-quality posts and durability fences; livestock dominates the landscape in the agroforestry system, for its regrowth capacity is favored for growth within the system.

\section{Importance value of tree species in the agroforestry system}

The use given to the different species involves a selective change in the growth pattern of these, this influence determined by the man is the main factor that modifies the natural ecosystems in systems sustainable use in many occasions. In the table below we can see the importance value of species found in the agroforestry system, where the species with the highest importance to this system is the tecolhuixtle (mimosa benthamii) with $114 \%$, this clearly demonstrates the selective pressure of the inhabitants of Ajuchitlán to this spice given its characteristics of use, the same way we can see that the Cuatecomate (Crescentia alata) has $50 \%$ of importance in the system from the rest of the other species, also it has desirable characteristics that allow its permanence within the system (Table 3 ).

The species found within this system have more than one use, there are medicinal as cuatecomata (Crescentia alata), cuachalalate (Amphipterygiumadstringens), Granjel(Randia echinocarpa) and stick Brazil (Haematxylum brasiletto) also excel fuel use as cubata (Acacia cochliacantha), quiebracho (Lonchocarpus rugosus), brazilwood (Haematxylum brasiletto), and forage value as Guazima (Guazuma ulmifolia), kills rat (Gliricidia sepium) and cubata (Acaciacochliacantha).

The index values of importance are directly related to the rate of cultural importance, as the tree species showed high importance values are the same as had greater cultural appreciation, tree selection in the SBC mountain range of Huautla, it corresponds to the needs of rural families use. 
Cuadro 3. Valor de importancia de las especies arbóreas en el sistema agrosilvopastoril.

Table 3. Value of important tree species in the agroforestry system.

\begin{tabular}{llllll}
\hline Nombre común & Nombre científico & DR & DmR & FR & VI \\
\hline Cuatecomate & Crescentia alata & 15.94 & 15.22 & 18.96 & 50.13 \\
Tecolohuiztle & Mimosa benthamii & 38.53 & 44.45 & 31.03 & 114.025 \\
Quiebracho & Lonchocarpus rugosus & 9.54 & 7.56 & 10.34 & 27.44 \\
Palo Brasil & Haematxylum brasiletto & 5.315 & 2.08 & 5.17 & 12.56 \\
Querengue & Vitex pyramidata & 3.98 & 4.95 & 3.44 & 12.38 \\
Cinco negritos & Lantana cámara & 1.32 & 0.62 & 1.72 & 3.68 \\
Grangel & Randia echinocarpa & 6.64 & 2.97 & 5.17 & 14.78 \\
Tepehuaje & Lysiloma acapulcense & 2.72 & 2.54 & 3.44 & 8.71 \\
Guazima & Guazuma ulmifolia & 1.32 & 2.24 & 1.72 & 5.29 \\
Linaloe & Bursera aloexylon & 1.32 & 0.19 & 1.72 & 3.25 \\
Copal & Bursera bipinnata & 1.36 & 0.26 & 1.72 & 3.35 \\
Mata rata & Gliricidia sepium & 3.98 & 5.18 & 5.17 & 14.34 \\
Cuachalalate & Amphipterygium adstringens & 3.98 & 4.16 & 5.17 & 13.32 \\
Cubata & Acacia cochliacantha & 3.98 & 7.33 & 5.17 & 16.49 \\
Total & & 99.99 & 99.81 & 100 & 299.81 \\
\hline
\end{tabular}

$\mathrm{DR}=$ Densidad relativa; $\mathrm{DmR}=$ dominancia relativa; $\mathrm{FR}=$ frecuencia relativa; $\mathrm{VI}=$ valor de importancia de la especie arbórea.

Los valores del índice de importancia se relacionan directamente con el índice de importancia cultural, ya que las especies arbóreas que presentaron altos valores de importancia son las mismas que tuvieron mayor grado de apreciación cultural, la selección de árboles en la SBC de la Sierra de Huautla, se corresponde con las necesidades de uso de las familias campesinas.

\section{Conclusiones}

El valor cultural de las especies arbóreas en el ejido de Ajuchitlán está relacionado directamente por los diferentes usos asignados, el análisis las ubica en la categoría de especies de uso múltiple, ya que satisfacen necesidades del núcleo familiar en más de una categoría de uso, así mismo la presión de selección de las especies forestales dentro de los sistemas de producción son el resultado del aprovechamiento por los diferentes usos de estas especies, con lo cual se crea un sistema de manejo agroforestal que permite la reproducción, propagación y manejo sustentable de las especies. Este manejo fue perfeccionado por las comunidades rurales a través del tiempo con la constante interacción de los recursos de la selva baja caducifolia generando y acumulando conocimientos locales en el manejo, aprovechamiento y reproducción de las especies arbóreas.

\section{Conclusions}

The cultural value of tree species in the common of Ajuchitlán is directly by the different uses assigned, analysis places them in the category of multipurpose species because they meet needs of the household in more than one category of use, same selection pressure of forest species in production systems are the result of the use by the different uses of these species, which a system of agroforestry that allows reproduction, propagation and sustainable management of species is created. This operation was perfected by rural communities over time with constant interaction of resources deciduous forest generating and accumulating local knowledge in the management, use and reproduction of tree species.

\section{End of the English version}

\section{Literatura citada}

Altieri, A. 1993. Agroecología, conocimiento tradicional y desarrollo rural sustentable. Porrúa. México. 671-679 pp.

Argueta, A. (coord.). 1994. Atlas de las plantas de la medicina tradicional mexicana .Tomos I, II y III. Instituto Nacional Indigenista, México. 
Díaz, T. M. G. P.; Ortizm, B. y Núñez, R. I. 2004. Interculturalidad, saberes campesinos y educación. El Colegio de Tlaxcala, Fundación Böll; SEFOA, Tlaxcala. 209 p.

Dirzo, R. 1996. Diversidad de flora mexicana. Cemex, México, 191 p.

Dorado, O. Arias, D. M; Alonso, G. y Maldonado, B. 2005. Educación para la biodiversidad a través de la universidad pública en áreas naturales protegidas: el caso de la Reserva de la Biosfera Sierra de Huautla, Morelos. Universidad Autónoma de Morelos. México. $26 \mathrm{p}$.

Lot, A. y Chiang, F. 1986. Manual del herbario. Administración y manejo de colecciones, ténicas de recolección y preparación de ejemplares botánicos, Departamento de Botánica, Instituto de Biología y Consejo Nacional de flora de México. UNAM. 142 p.

Miranda, F. y Hernández, X. E. 1963. Los tipos de vegetación de México y su clasificación. Bol. Soc. Bot. 29:1-179.
Monroy, R.; Ayala, I. 2003. Importancia del conocimiento etnobotánico frente al proceso de urbanización. Universidad Autónoma del Estado de Morelos. México.

Otero, Z. R. 2005. Árboles nativos de usos múltiples y sistemas agroforestales tradicionales en el municipio de Acapulco de Juárez, Guerrero. Tesis de Grado. Universidad Autónoma Chapingo, Texcoco, México. 181 p.

Pérez, R. M.L. y Argueta, V. A. 2011. Saberes indígenas y diálogo intercultural. Cultura científica y saberes locales. Año 5, núm. 10. México. 35-56 pp.

Rzedowski, J., 2006. Vegetación de México. 1ra. Edición digital, ComisiónNacional para el Conocimiento y Uso de la Biodiversidad, México. 504 p.

Toledo, V. M. 2012. Red de etnoecología y patrimonio biocultural. Conacyt, México. D. F. 60 p. 